\title{
State Scholarship and Loan Forgiveness Programs in the United States: Forgotten Driver of Access to Health Care in Underserved Areas
}

\author{
Karen W. Geletko1, Robert G. Brooks², Andrew Hunt ${ }^{3}$, Leslie M. Beitsch ${ }^{1}$ \\ ${ }^{1}$ Florida State University College of Medicine, Tallahassee, USA \\ ${ }^{2}$ University of South Florida College of Medicine, Tampa, USA \\ ${ }^{3}$ Nova Southeastern University College of Osteopathic Medicine, Fort Lauderdale, USA \\ Email: karen.geletko@med.fsu.edu
}

Received 11 June 2014; revised 27 July 2014; accepted 11 August 2014

Copyright (C) 2014 by authors and Scientific Research Publishing Inc. This work is licensed under the Creative Commons Attribution International License (CC BY). http://creativecommons.org/licenses/by/4.0/

\section{(c) (i) Open Access}

\section{Abstract}

State-supported programs providing loans and scholarships in exchange for service in underserved areas provide an important source of financial support for medical students while encouraging them to select careers in primary care. The purpose of this research was to seek a better understanding of these often unheralded but important state sources of support, and learn if they have continued to grow in the twenty-first century. Administrative data were obtained on statesupported programs operating in 2008 that provided financial support to students, resident or practicing physicians, physician assistants, nurse practitioners, certified nurse midwives, dentists, and licensed mental healthcare providers in exchange for service in an underserved area. The authors identified numbers, types of state-supported programs, program workforce strength, and features of state programs. In 2008, 75 state programs, operating in 37 states, collectively had 5113 program participants under contract. Loan repayment programs $(n=42,56 \%)$ were the most common type of state-supported programs. Practitioners signed initial contracts in 2008 totaled 1173, with more non-physicians $(n=681,58 \%)$ signing initial contracts than physicians $(n=$ 492, 42\%). Additionally, 2803 practitioners were serving in programs in 2008. Field placement was also slightly greater among non-physicians in $2008(n=1433,51 \%)$ than physicians $(n=1370$, 49\%). State support-for-service programs remains an important source of financial assistance for those willing to make service commitments in underserved areas. Moreover, these programs continue to increase in size, even amidst the economic malaise, and provide an obligated primary care workforce in underserved areas. 


\section{Keywords}

\section{Primary Care Workforce, Medical Education, Loan Forgiveness, Access to Care}

\section{Introduction}

Compared with other developed nations, the United States (US) has substantially lower percentages of primary care physicians relative to specialists [1]-[4]. Primary care providers comprise only about 35\% of the nation's physician workforce and $37 \%$ of the physician assistant workforce [5]. Furthermore, a recent study predicted that expected population growth, coupled with the aging of the population, will expand primary care physicians' workloads by one-third in the next two decades [6]. Such future workload projections indicate growing demand for primary care services, even as fewer American medical school graduates are choosing to enter primary care residency programs [1] [7]-[9]. Medical school graduates selecting primary care residencies dropped by half from the mid-1990s to the mid-2000s, and from 2000 to 2005 the percentage of medical school graduates in family medicine residencies declined from $14 \%$ to $7 \%$ [7] [10].

Primary care physicians earn approximately half of the income of their specialty colleagues, a fact not lost on those students traversing the medical education pipeline [11]-[14]. Recently this gap has been widening, while at the same time overall medical education indebtedness is increasing [4] [15]-[17]. In 2011, 86\% of medical school graduates had education debt, with an average debt of $\$ 161,290$ [18]. Given the escalating costs of medical education, current incentives are misaligned to encourage medical students to select careers in primary care and to practice in underserved communities. The critical question is: What financial incentives will enable students who are interested in primary care practice in rural and underserved areas to fulfill their career goals, surmounting the challenges described?

One such mechanism has been the National Health Service Corps (NHSC). This program, in existence for 40 years, matches students and residents to areas of need in exchange for scholarship and loan repayment incentives. NHSC has been recognized as an important program in the quest to realign physician maldistribution in the US [19]. Less well known as part of the solution for steering more recent graduates to primary care and underserved areas, are the programs which have been set up in many states to provide scholarships and loans in exchange for practice in underserved areas. Recent work found loan forgiveness programs to be among the most financially advantageous for indebted medical school graduates selecting careers in primary care [20].

With more recent evidence of declining numbers of primary care physicians, and sky-rocketing student loan indebtedness, we believed it a propitious time to review the status of state-associated scholarship and loan repayment programs across the US for comparison with the status of such programs in the mid-1990s. Our study seeks to better understand these often unheralded but important state sources of support, and learn if they have continued to grow in the first decade of the twenty-first century. In short, do they remain a viable alternative for addressing student loan indebtedness and societal needs for increasing the primary care workforce in rural and underserved areas of the US?

\section{Methods}

In order to record and compare trends in state support-for-health service programs over time we reviewed and utilized where possible the methodology previously reported by Pathman et al. [19]. This previous study of state loan and scholarship programs identified five different program categories (scholarship, loan, resident support, loan repayment, and direct financial support), and we have done likewise.

\subsection{Identifying Eligible State Programs}

A mixed mode and repetitive approach was utilized to identify eligible support-for-service programs in the calendar year 2008 in all 50 states using searches of available compendia and telephone contacts with individuals and program offices. Compendia included online sources and other available documents; previous studies; lists of state primary care office directors and administrators; lists of state loan repayment program contacts; officials in state offices of rural health and primary care, state public health offices and state higher education financial 
aid authorities, and other online sources, printed materials and documents available to the public. Our eligibility criteria for programs were determined using similar methods established by Pathman et al. [19]. Eligible programs were designated as those that 1) provided financial support to students, resident or practicing physicians (MD or DO), physician assistants (PA), nurse practitioners (ARNP), certified nurse midwives, dentists, and licensed mental healthcare providers (e.g. registered or licensed psychologists, marriage/family therapists or clinical social workers); 2) had a service requirement or option in a defined medically underserved setting across a given state rather than solely in one region or community within a state; 3 ) supported practitioners with state public dollars, community funds, recurring program dollars, or funds from private nonprofit sources but do not have majority direct federal support; 4) delivered financial support directly to practitioners or to an educational or financial entity on their behalf, such as a medical school or commercial lender; 5) and were operating in the calendar year 2008. Our criteria differed from Pathman et al. [19] in that we included dentists and licensed mental health providers in the list of eligible programs. Similar to Pathman, et al. [19], we excluded service-requiring programs for registered nurses, pharmacists, and other health care workers if physicians and mid-level practitioners did not comprise the majority of obligated participants.

\subsection{Data Collection}

A survey instrument was developed and used for data collection. Survey respondents were contacted via telephone and asked to participate in the study. The survey was administered to program representatives (in most cases, program directors) of identified eligible programs either through semi-structured telephone interviews using the survey $(n=65)$, or in a few cases $(n=10)$, the survey was mailed or emailed to the program representative at their request for them to complete and return at their convenience. The survey sought to obtain administrative data such as program classification, administering organization, financial support and funding sources, eligible service sites, contract terms for participants, types of obligated practitioners, number of practitioners under contract, field strength, and retention rate after completed obligation. Programs' representatives provided all of the information on program characteristics presented. In some instances, program representatives were unable to provide information on all survey questions, generally due to lack of historical records related to those specific areas. Data collection began in June, 2009 and ended in August, 2010. The Florida State University Institutional Review Board (IRB) approved the study.

\subsection{Analyses}

We tabulated the number of eligible programs in 2008 by type, using program classification types developed by Pathman et al. [19]. We utilized descriptive statistics to portray the distribution of programs throughout the nation, as well as essential program features such as administering organization, funding sources, eligible service sites, and contract terms. Finally, we calculated the total number of new contracts and field placement by adding data across programs.

\section{Results}

\subsection{State Programs (Numbers and Flux)}

Ninety-two eligible programs were identified in 42 states in 2008. Responses were received from 75 (81.5\%) programs in 37 states. Loan repayment programs $(n=42,56 \%)$ were the most numerous type of program available in 2008, with fewer scholarship ( $\mathrm{n}=12,16 \%)$, loan $(\mathrm{n}=11,15 \%)$, direct financial incentive $(\mathrm{n}=7,9 \%)$ and resident support $(\mathrm{n}=3,4 \%)$ programs (Table 1$)$.

\subsection{Distribution of Support-for-Service Programs across States}

Of the 37 states that offered eligible state-level support-for-service programs, 18 (49\%) offered two or more programs. Of those 18 states offering more than one program, eight (44\%) were from the South region and seven (39\%) were states located in the North Central region of the country. State-funded programs were somewhat less common among states in the West $(n=5,14 \%)$ and Northeast $(n=6,16 \%)$ compared with states in the South $(n=12,32 \%)$ and North Central $(n=4,38 \%)$ regions (Figure 1$)$. 
Table 1. Classification of state scholarship and loan forgiveness programs in the US.

\begin{tabular}{|c|c|c|c|c|c|}
\hline Program Type & Number in 2008 & Eligible Individuals & Service & Use of Funds & Typical Design \\
\hline Scholarship & 12 & Students & Required & $\begin{array}{l}\text { Up-front } \\
\text { training costs }\end{array}$ & $\begin{array}{l}\text { Student scholarships for tuition, fees, books, } \\
\text { and living expenses, with service expected } \\
\text { after training }\end{array}$ \\
\hline Loan & 11 & Students & Optional & $\begin{array}{l}\text { Up-front } \\
\text { training costs }\end{array}$ & $\begin{array}{l}\text { Student loans to students for tuition, fees, books, } \\
\text { and living expenses; loan is repaid after training } \\
\text { either financially or by providing service }\end{array}$ \\
\hline Resdient Support & 3 & $\begin{array}{l}\text { Junior or senior } \\
\text { residents }\end{array}$ & Required & Variable & $\begin{array}{l}\text { Funds for junior and occasionally senior } \\
\text { residents with service expected after training }\end{array}$ \\
\hline Loan Repayment & 42 & $\begin{array}{l}\text { Senior residents } \\
\text { and practitioners }\end{array}$ & Required & $\begin{array}{l}\text { Repayment of } \\
\text { educational loans }\end{array}$ & $\begin{array}{l}\text { Funds to repay outstanding education loans of } \\
\text { graduating residents and practitioners in } \\
\text { exchange for service }\end{array}$ \\
\hline $\begin{array}{l}\text { Direct Finanical } \\
\text { Incentive }\end{array}$ & 7 & $\begin{array}{l}\text { Senior residents } \\
\text { and practitioners }\end{array}$ & Required & Unrestricted & $\begin{array}{l}\text { Unrestricted incentive funds for graduating } \\
\text { residents and practitioners in exchange for service }\end{array}$ \\
\hline
\end{tabular}

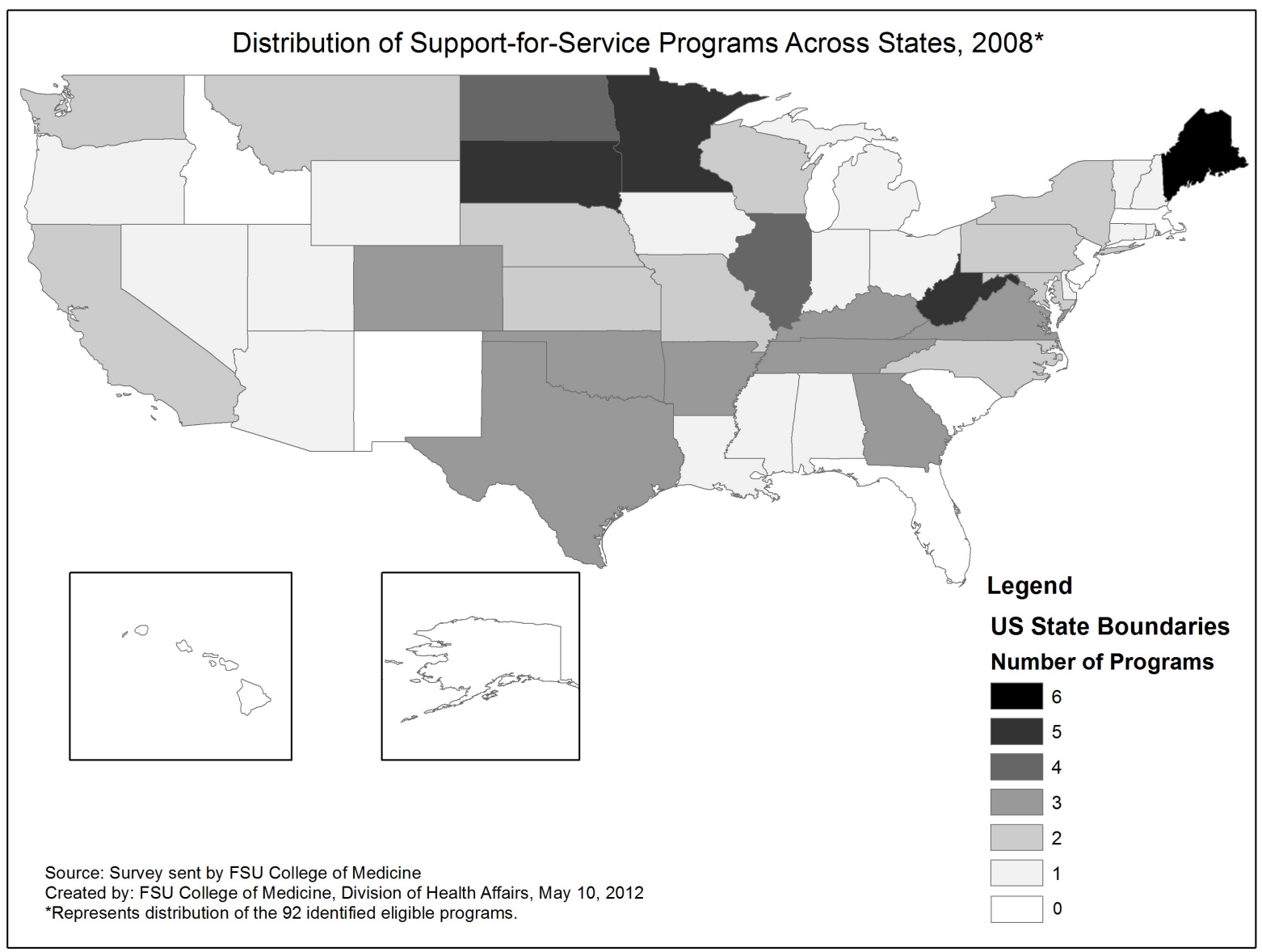

Figure 1. Distribution of support-for-service programs across states, 2008.

\subsection{Program Workforce}

In 2008, the 75 state programs collectively had a total of 5113 program participants (students, residents, and actively practicing providers) under contract. This same year, the state programs collectively signed initial contracts with 1173 practitioners of whom 492 (42\%) were physicians and 681 (58\%) were non-physicians (Table 2).

The state programs had a total of 2803 practitioners serving their obligations in 2008, of whom 1370 (48.9\%) 
Table 2. Number of practitioners signing first contract and serving in programs in 2008.

\begin{tabular}{|c|c|c|c|}
\hline \multirow{3}{*}{ Program Type } & \multicolumn{3}{|c|}{ Number of Practitioners } \\
\hline & Physicians & Non-Physicians ${ }^{\mathrm{a}}$ & Program Totals \\
\hline & \multicolumn{3}{|c|}{ Number of Practitioners Signing First Contract } \\
\hline Scholarship & 45 & 275 & 320 \\
\hline Loan & 143 & 26 & 169 \\
\hline Resident Support & 45 & 0 & 45 \\
\hline Loan Repayment & 252 & 317 & 569 \\
\hline Direct Financial Incentive & 7 & 63 & 70 \\
\hline \multirow[t]{2}{*}{ Total } & 492 & 681 & 1173 \\
\hline & \multicolumn{3}{|c|}{ Number of Practitioners Serving in Programs } \\
\hline Scholarship & 332 & 481 & 813 \\
\hline Loan & 243 & 3 & 246 \\
\hline Resident Support & 222 & 40 & 262 \\
\hline Loan Repayment & 559 & 844 & 1403 \\
\hline Direct Financial Incentive & 14 & 65 & 79 \\
\hline Total & 1370 & 1433 & 2803 \\
\hline
\end{tabular}

${ }^{\mathrm{a}}$ Non-physicians included physician assistants, nurse practitioners, certified nurse midwives, dentists, and licensed mental healthcare providers.

were physicians and 1433 (51.1\%) were non-physicians (Table 2). Of the physicians serving obligations, the majority were allopathic $(n=758,72.7 \%)$ and practicing in Family Medicine $(n=706,75.1 \%)$ (Table 3). Only 16 of the 75 programs monitored physician retention in the service area after obligations were completed. Among these 16 programs, the average percentage of physicians that remain in the service area following their obligation was $79 \%$. The mean number of physicians defaulting on their service obligation was 8.6 per program.

\subsection{Features of State Programs}

State programs were administered by various state organizations and offices, with the state office of rural health ( $n=21$ of 75, 28\%) being the most common administrative organization in 2008 (Table 4). Additionally, 24\% $(n=18$ of 75$)$ of programs reported a combination of two organizations as the administrating entity with the state office of rural health and state office of primary care $(n=12$ of $18,67 \%)$ being the most common combination. Other arrangements included state office of rural health and other state health office ( $\mathrm{n}=3$ of $18,17 \%$ ), state higher education financial authority and other state health office $(n=2$ of $18,11 \%)$, and individual medical school and private organization ( $\mathrm{n}=1$ of $18,5 \%)$. Only two (3\%) of 75 programs were administered by individual medical schools. Forty-nine (68\%) of the 72 programs that reported a funding source were funded entirely ( $\mathrm{n}=32$ of $72,65 \%)$, or partially $(\mathrm{n}=17$ of $72,35 \%)$ by state appropriations. At least some federal funding was received by 15 (21\%) of 72 programs.

Programs used a variety of approaches to define sites where practitioners could serve their obligations. Twenty (27\%) of 73 programs used federal designation criteria solely, and 23 (32\%) of 73 programs combined federal Health Professional Shortage Areas (HPSAs) or Medically Underserved Areas (MUAs) with other state designations. The remaining 30 (41\%) of 73 programs used entirely state-specific designations, such as community assessments and census numbers, to determine site eligibility.

Contract terms for practitioners varied greatly by program. Financial support opportunities, for the 71 programs indicating a range, varied from $\$ 2000$ to $\$ 50,000$ per year with a median of $\$ 20,000$. The minimum obligation of service for the 66 programs reporting a range, varied from six months to seven years with a median of three years. Financial penalties for practitioners who defaulted on their service obligation while under contract 
Table 3. Program physician workforce in 2008.

\begin{tabular}{|c|c|}
\hline \multicolumn{2}{|c|}{ Physician Field Placement $n=41$} \\
\hline MD & 758 \\
\hline DO & 284 \\
\hline Total $^{\mathrm{a}}$ & 1042 \\
\hline \multicolumn{2}{|c|}{ Physician Field Placement by Specialty $n=40$} \\
\hline Family Medicine & 706 \\
\hline Internal Medicine & 65 \\
\hline General Pediatrics & 67 \\
\hline Obstetrics and Gynecology & 31 \\
\hline Psychiatry & 29 \\
\hline General Surgery & 8 \\
\hline Other Specialities & 31 \\
\hline Total $^{\mathrm{a}}$ & 940 \\
\hline \multicolumn{2}{|c|}{ Physician Retention in Service Area after Completed Obligation ${ }^{\mathrm{b}}(\%) \mathrm{n}=16$} \\
\hline Median & $79 \%$ \\
\hline Minimum & $40 \%$ \\
\hline Maximum & $100 \%$ \\
\hline \multicolumn{2}{|c|}{ Physicians Defaulting on Service Obligation ${ }^{c} n=46$} \\
\hline Median & 8.6 \\
\hline Minimum & 1 \\
\hline Maximum & 61 \\
\hline
\end{tabular}

ranged from none ( $n=9$ of $74,12 \%)$ to either exclusively repaying principal ( $n=3$ of $74,4 \%)$, interest $(n=4$ of $74,5 \%)$, or incurring penalties ( $n=5$ of $74,7 \%$ ); but the most common penalty was varying combinations of the three $(n=53$ of $74,72 \%)$ (data not shown).

\section{Discussion}

\subsection{Changing Spectrum of State Programs}

The number of state-support for service programs has slightly increased over the last decade from 82 programs in 1996 to 92 programs in 2008. However, the composition of programs has changed since 1996, with fewer scholarship, and more loan repayment, programs in 2008. Pathman et al. [19] reported 18 more scholarship programs than we did, but we noted 13 additional loan repayment programs.

While the discrepancy in scholarship programs from 1996 to 2008 is significant, there are several possible factors potentially influencing this shift. Economic hardships and budget cuts in many states have forced decreased funding in state-supported programs and may be responsible for the loss of several programs [21]-[23]. We were able to confirm that five scholarships programs active in 1996 either have since been eliminated or no longer receive funding. There were an additional eight scholarship programs active in 1996 that we were unable to document in 2008, also possibly linked to loss of program financial support.

Previous research on the NHSC has shown that loan repayment programs cost less per year of obligated service, 
Table 4. Characteristics of state support-for-service programs in 2008.

\begin{tabular}{|c|c|}
\hline Administrating Organization, No. (\%) & $\mathrm{n}=75$ \\
\hline Individual medical school & $2(3)$ \\
\hline State higher education financial authority & $7(9)$ \\
\hline State office of rural health & $21(28)$ \\
\hline State office of primary care & $8(11)$ \\
\hline Other state health office & $5(7)$ \\
\hline Other state non-health & $10(13)$ \\
\hline Private organization & $4(5)$ \\
\hline Combination of organizations & $18(24)$ \\
\hline Program Funding Source, No. $(\%)^{\mathrm{a}}$ & $\mathrm{n}=72$ \\
\hline State appropriations & $49(68)$ \\
\hline Communities & $14(19)$ \\
\hline Reoccurring program dollars & $6(8)$ \\
\hline Fees and taxes on healthcare providers & $4(5)$ \\
\hline Private & $8(11)$ \\
\hline Federal & $15(21)$ \\
\hline Miscellaneous & $15(21)$ \\
\hline \multicolumn{2}{|l|}{ Eligible Service Sites } \\
\hline Criteria for Eligible Sites, No. (\%) & $\mathrm{n}=73$ \\
\hline State-specific designation & $30(41)$ \\
\hline Federal HPSA and/or MUA & $20(27)$ \\
\hline State designation combined with HPSA and/or MUA & $23(32)$ \\
\hline Site Eligibility Restrictions, No. (\%) & $\mathrm{n}=73$ \\
\hline Solely rural & $22(30)$ \\
\hline Preference for rural & $22(30)$ \\
\hline No preference & $27(36)$ \\
\hline Solely urban & $2(3)$ \\
\hline \multicolumn{2}{|l|}{ Contract Terms for Physicians } \\
\hline Annual Financial Support, \$ & $\mathrm{n}=71$ \\
\hline Median & 20,000 \\
\hline Minimum & 2000 \\
\hline Maximum & 50,000 \\
\hline Minimum Duration of Service (mo) & $\mathrm{n}=66$ \\
\hline Median & 36 \\
\hline Minimum & 6 \\
\hline Maximum & 84 \\
\hline
\end{tabular}

${ }^{\mathrm{a}}$ Many programs reported more than one funding source. 
and recipients have a higher rate of retention at their service site after their obligation is complete when compared to scholarships programs [24]. The recent economic malaise may have influenced a paradigm shift in program type from scholarship to loan repayment. Several states that reported scholarship programs in 1996, did not report any loan repayment programs at that time. However, those same states did not report any scholarship programs in 2008, but did report loan repayment programs. Therefore, it is plausible, that some of these programs changed program type from scholarship to loan repayment in order to be more cost effective.

Finally, types of program distinctions are not always clear. A handful of support-for-service programs are titled "scholarship/loan repayment" and the program classification is dependent upon when the program participant applies for the support. A participant, applying prior to their educational enrollment, would receive a scholarship, whereas a participant applying after their education has begun would receive loan support. Therefore, some of the support for service programs identified in 2008 and classified by the survey respondent as either "loan" or "loan repayment" could potentially be the same program identified in 1996, but classified previously as "scholarship".

\subsection{Changes in Practitioner Participation}

Overall, more physicians signed initial contracts and were serving in programs in 1996, but more non-physicians signed initial contracts and were serving in programs in 2008. Non-physicians signing initial contracts in 2008 ( $n=681)$ substantially increased (266\% greater) compared with this group's initial sign-up in 1996 ( $n=256)$. Slightly more physicians were serving in programs in $2008(n=1370)$ than in $1996(n=1306)$. Field placement was also greater among non-physicians in $2008(n=1433)$ than in $1996(n=370)$.

While the physician workforce has continued to increase over the past decade, the growth in physician supply is accounted for by increasing numbers of non-primary care specialists [4]. Therefore, as an increasing number of physicians are choosing to go into specialty medicine, states have made policy changes to emphasize the role of mid-level practitioners to fill the gaps in primary care, as exemplified by the number of mid-level scholarship recipients.

\subsection{Limitations}

Our study is not without limitations, most significant being the omission of 17 identified eligible programs. Despite repeated attempts (spanning the two-year data collection period) to contact the program representatives of non-respondents, we received either no feedback or reluctance by the program representative to participate, mostly due to time constraints. Additionally, the sample size for individual survey questions varied, some program contacts did not provide answers to all survey questions. Generally, in these cases, the answer to the question was either not known by the program contact or the data sought was not available. Turnover among program administrators in state and governmental entities compounded these data collection problems as well. Many of the programs had administrators or representatives who had not been in the position long, or in some cases, were acting administrators. In these situations, the program representative often lacked the program background and knowledge needed to provide complete responses to survey questions.

\subsection{Conclusions}

Since the data were collected in 2008, changes have occurred in state budgets and in the NHSC that have potentially affected the status of state support-for-service programs. As noted previously, funding for many state programs has been reduced and even eliminated in some cases [21]-[23]. If states continue to experience budget challenges, state support-for-service programs may not be able to meet the demand from practitioners and communities to fill positions [25]. On the other side of the spectrum, the American Recovery and Reinvestment Act (ARRA) and the Affordable Care Act (ACA) have provided additional funding to the NHSC, essentially doubling the size of its workforce support [26] [27]. With the expansion of the federal program, state programs may find themselves competing with, rather than complimenting, the NHSC [25]. Many state programs are currently reporting a decline in the number of applicants and some are finding it difficult to fill positions [25].

The findings of our study, coupled with the increasing importance of securing a stable primary care workforce, have several implications for future research. First, our hypothesis of scholarship programs transitioning to loan repayment programs requires validation. Ideally, future research should track state-based programs over time with an eye towards identifying best practices and most cost effective program characteristics to share with 
states considering such type programs to meet local needs. Second, the enactment of the ACA will lead to greater demand for primary care services. Although several new medical schools have been established in the US in the last decade, few are committed to producing a primary care workforce. Future research needs to examine whether physicians are vacating the primary care field, leaving mid-level practitioners as the predominant primary care workforce, particularly in underserved communities. Third, future research should also examine how the expansion of the NHSC under the ACA has affected the primary care pipeline: Is it being accessed primarily by physicians or mid-level practitioners? Fourth, the ACA has made a short-term commitment to increasing reimbursement rates for primary care physicians. This commitment needs to be sustained long enough to facilitate research to assess its impact on numbers of physicians entering and remaining in primary care in comparison with specialty care.

Providing access to care for all Americans, and preferably a medical home in a primary care based model, continues to be a key goal for many health care advocates in this country. While the ultimate solutions may relate to an acceptable vision of health reform, a well-trained, primary care workforce available and willing to work in underserved areas, is an instrumental component. Financial barriers continue to be an important barrier for at least some students, residents, and physicians, as they weigh their specialty choice and practice location [28] [29]. Exacerbation of the historic misalignment between workforce specialty needs and disincentives for students to enter primary care creates greater dependency upon external sources of support. Programs, like the state-level initiatives studied, continue to be an important source of financial support for those willing to make service commitments in underserved areas. Furthermore, previous research indicates these programs are not only successful at attracting students to primary care, but that state obligated physicians are more satisfied and remain longer in their practice than non-obligated physicians [11] [30] [31]. Health care advocates and policy makers must not overlook the state role in providing loan and scholarship opportunities to meet their unique and growing needs to expand access to quality health care.

\section{References}

[1] Bodenheimer, T. and Pham, H.H. (2010) Primary Care: Current Problems and Proposed Solutions. Health Affairs (Millwood), 29, 799-805. http://dx.doi.org/10.1377/hlthaff.2010.0026

[2] Bodenheimer, T. (2006) Primary Care-Will It Survive? The New England Journal of Medicine, 355, 861-864. http://dx.doi.org/10.1056/NEJMp068155

[3] Council on Graduate Medical Education (2009) Patient Care Physician Supply and Requirements: Testing COGME Recommendations; Summary of Eighth Report [Internet]. Executive Summary. Rockville (MD): COGME. http://www.cogme.gov/rpt8.htm

[4] Bodenheimer, T. and Grumbach, K. (2009) Understanding Health Policy: A Clinical Approach. 5th Edition, McGrawHill, New York.

[5] Phillips Jr., R.L. and Bazemore, A.W. (2010) Primary Care and Why It Matters for US Health System Reform. Health Affairs (Millwood), 29, 806-810. http://dx.doi.org/10.1377/hlthaff.2010.0020

[6] Colwill, J.M., Cultice, J.M. and Kruse, R.L. (2008) Will Generalist Physician Supply Meet Demands of an Increasing and Aging Population? Health Affairs (Millwood), 27, 232-241. http://dx.doi.org/10.1377/hlthaff.27.3.w232

[7] Pugno, P.A., Schmittling, G.T., Fetter Jr., G.T. and Kahn Jr., N.B. (2005) Results of the 2005 National Resident Matching Program: Family Medicine. Family Medicine, 37, 555-564.

[8] Force, A.G.P.T. (1993) AAMC Policy on the Generalist Physician. Academic Medicine, 68, 1-6. http://dx.doi.org/10.1097/00001888-199301000-00001

[9] Abrams, M.K., Nuzum, R., Mika, S. and Lawlor, G. (2011) How the Affordable Care Act Will Strengthen Primary Care and Benefit Patients, Providers, and Payers. Issue Brief (Commonw Fund), 1, 1-28.

[10] American College of Physicians (2008) How Is a Shortage of Primary Care Physicians Affecting the Quality and Cost of Medical Care? American College of Physicians, Philadelphia.

[11] Woodworth, P.A., Chang, F.C. and Helmer, S.D. (2000) Debt and Other Influences on Career Choices among Surgical and Primary Care Residents in a Community-Based Hospital System. American Journal of Surgery, 180, 570-575. http://dx.doi.org/10.1016/S0002-9610(00)00543-2

[12] Marci, C.D. and Roberts, T.G. (1998) The Increasing Debt of Medical Students: How Much Is Too Much? JAMA, 280, 1879-1880.

[13] Levinsky, N.G. (1993) Recruiting for Primary Care. New England Journal of Medicine, 328, 656-660. http://dx.doi.org/10.1056/NEJM199303043280913 
[14] Schwartz, R.W., Jarecky, R.K., Strodel, W.E., Haley, J.V., Young, B. and Griffen Jr., W.O. (1989) Controllable Lifestyle: A New Factor in Career Choice by Medical Students. Academic Medicine, 64, 606-609.

[15] Naradzay, J.F. (1998) Into the Deep Well: The Evolution of Medical School Loan Debt. JAMA, 280, 1881, 1883.

[16] Jolly, P. (2005) Medical School Tuition and Young Physicians’ Indebtedness. Health Affairs (Millwood), 24, 527-535. http://dx.doi.org/10.1377/hlthaff.24.2.527

[17] American Medical Association (1997) The Financing of Medical School—Student Loan/Higher Education Act. Chicago.

[18] Association of American Medical Colleges (2012) Medical Student Education: Costs, Debt, and Loan Repayment Facts. Washington DC.

[19] Pathman, D.E., Taylor Jr., D.H., Konrad, T.R., King, T.S., Harris, T., Henderson, T.M., et al. (2000) State Scholarship, Loan Forgiveness, and Related Programs: The Unheralded Safety Net. JAMA, 284, 2084-2092. http://dx.doi.org/10.1001/jama.284.16.2084

[20] Youngclaus, J.A., Koehler, P.A., Kotlikoff, L.J. and Wiecha, J.M. (2013) Can Medical Students Afford to Choose Primary Care? An Economic Analysis of Physician Education Debt Repayment. Academic Medicine, 88, 16-25.

[21] Banning, T. (2011) Texas Health Bill Provides Building Blocks for Reform. Houston Chronicle. http://www.chron.com/opinion/outlook/article/Texas-health-bill-provides-building-blocks-for-2079799.php

[22] Oregon Rural Health Association (2010) Oregon Rural Health Association Holds Rural Health Policy Summit. http://www.orha.org/PolicySummit.htm

[23] Virginia Office of the Governor (2010) Governor's Recommendations. Virginia Office of the Governor, Richmond.

[24] United States General Accounting Office (1995) National Health Service Corps Opportunities to Stretch Scarce Dollars and Improve Provider Placement: Report to the Chairman, Committee on Labor and Human Resources, US Senate. Washington DC.

[25] Pathman, D.E., Morgan, J.C., Konrad, T.R. and Goldberg, L. (2012) States’ Experiences with Loan Repayment Programs for Health Care Professionals in a Time of State Budget Cuts and NHSC Expansion. Journal of Rural Health, 28, 408-415. http://dx.doi.org/10.1111/j.1748-0361.2012.00409.x

[26] US Department of Health and Human Services (2011) Affordable Care Act Bolsters the Primary Care Workforce in Medically Underserved Communities. US Department of Health and Human Services, Washington DC.

[27] US Department of Health and Human Services (2013) National Health Service Corps Expands the Primary Care Workforce. US Department of Health and Human Services, Washington DC.

[28] Pathman, D.E., Konrad, T.R., King, T.S., Spaulding, C. and Taylor, D.H. (2000) Medical Training Debt and Service Commitments: The Rural Consequences. Journal of Rural Health, 16, 264-272. http://dx.doi.org/10.1111/j.1748-0361.2000.tb00471.x

[29] Rosenblatt, R.A. and Andrilla, C.H. (2005) The Impact of US Medical Students’ Debt on Their Choice of Primary Care Careers: An Analysis of Data from the 2002 Medical School Graduation Questionnaire. Academic Medicine, 80, 815819. http://dx.doi.org/10.1097/00001888-200509000-00006

[30] Miller, J.B. and Crittenden, R.A. (2001) The Effects of Payback and Loan Repayment Programs on Medical Student Career Plans. Journal of Rural Health, 17, 160-164. http://dx.doi.org/10.1111/j.1748-0361.2001.tb00952.x

[31] Pathman, D.E., Konrad, T.R., King, T.S., Taylor Jr., D.H. and Koch, G.G. (2004) Outcomes of States' Scholarship, Loan Repayment, and Related Programs for Physicians. Medical Care, 42, 560-568. http://dx.doi.org/10.1097/01.mlr.0000128003.81622.ef 
Scientific Research Publishing (SCIRP) is one of the largest Open Access journal publishers. It is currently publishing more than 200 open access, online, peer-reviewed journals covering a wide range of academic disciplines. SCIRP serves the worldwide academic communities and contributes to the progress and application of science with its publication.

Other selected journals from SCIRP are listed as below. Submit your manuscript to us via either submit@scirp.org or Online Submission Portal.
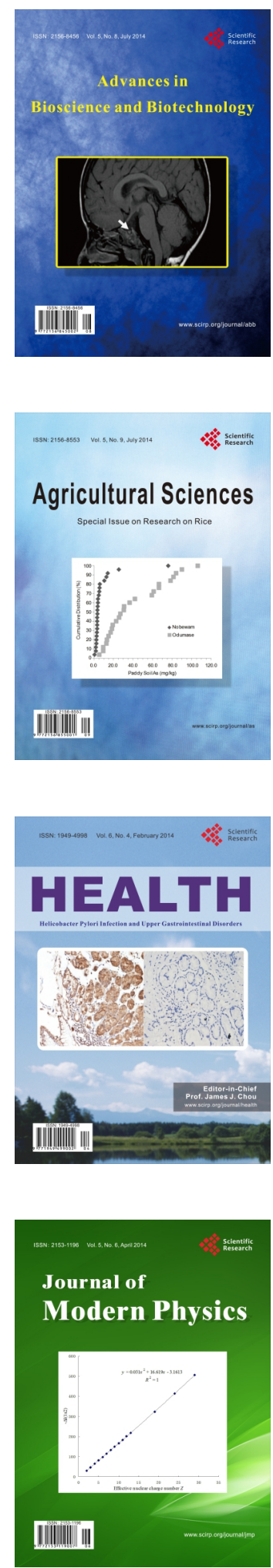
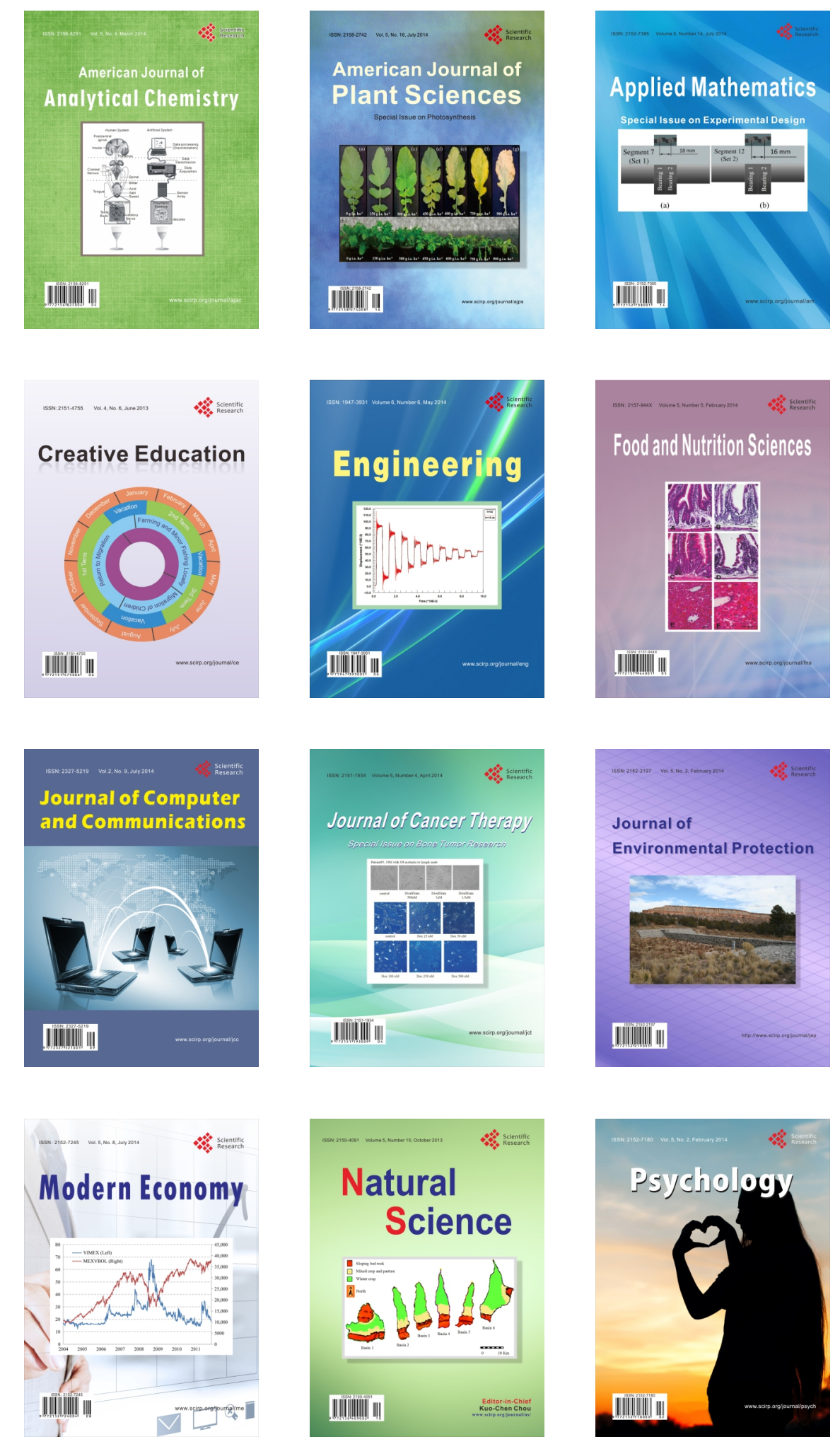